\title{
Pengembangan materi bahan ajar menulis puisi dengan menggunakan teknik pemodelan di SMPN I Tulungagung
}

\section{Marista Dwi Rahmayantis ${ }^{I^{*}}$, Nurlailiyah ${ }^{2}$}

Pendidikan Bahasa Indonesia, Universitas Nusantara PGRI Kediri, J1. Ahmad Dahlan No.76, Mojoroto, Kecamatan Mojoroto, Kota Kediri, Indonesia

I'maristadwi@unpkediri.ac.id ; lailiya86@unpkediri.ac.id

*Corresponding author: maristadwi@unpkediri.ac.id

\begin{tabular}{|c|c|c|}
\hline Artikel & Diterima: I7 September 2020 & Tersedia Daring: 31 Oktober 2020 \\
\hline \multicolumn{3}{|c|}{ ABSTRAK } \\
\hline $\begin{array}{l}\text { Keterampilan } \\
\text { dalam pembela } \\
\text { menggunakan } \\
\text { mengembangk } \\
\text { SMPN I Tulu } \\
\text { Prosedur peng } \\
\text { tahap revisi pr } \\
\text { evaluasi. Hasil } \\
\text { uji lapangan se } \\
\text { proses pembel }\end{array}$ & $\begin{array}{l}\text { 1is puisi siswa SMP masih sangat rendah serta belum ada } \\
\text { n. Kondisi tersebut mendorong peneliti untuk mengembang } \\
\text { ik pemodelan yang dapat digunakan oleh guru dalam proses } \\
\text { i, bahasa, dan sajian bahan ajar menulis puisi dengan mengg } \\
\text { ung. Rancangan penelitian yang digunakan adalah adaptasi } \\
\text { angannya meliputi (I) tahap prapengembangan, (2) tahap p } \\
\text { Bahan ajar yang telah dikembangkan memiliki tujuh unit } \\
\text { litian menunjukkan rerata (I) uji coba tim ahli sebesar } 90 \% \\
\text { n menulis puisi direkomendasikan menggunakan bahan ajar }\end{array}$ & $\begin{array}{l}\text { n ajar yang dapat digunakan oleh guru } \\
\text { materi bahan ajar menulis puisi dengan } \\
\text { elajaran. Penelitian ini bertujuan untuk } \\
\text { an teknik pemodelan yang dilakukan di } \\
\text { model pengembangan Dick and Carey. } \\
\text { mbangan dan uji coba produk, serta ( } 3 \text { ) } \\
\text { terdiri dari materi, contoh, latihan, dan } \\
\text { uji coba praktisi sebesar 9I\%, serta (3) } \\
\text { proses pembelajaran. Oleh karena itu, } \\
\text { ulis puisi dengan menggunakan teknik }\end{array}$ \\
\hline
\end{tabular}

\section{Kata Kunci Menulis puisi, Pengembangan bahan ajar, Teknik pemodelan}

\section{ABSTRACT}

Junior high school students' poetry writing skills are still very low and there are no teaching materials that teachers can use in learning. This condition encourages researchers to develop teaching materials for writing poetry using modeling techniques that teachers can use in the learning process. This study aims to develop the content, language, and presentation of teaching materials for writing poetry using modeling techniques carried out at SMPN I Tulungagung. The research design used is an adaptation of the Dick and Carey development model. The development procedure includes (I) the predevelopment stage, (2) the product development and testing stage, and (3) the product revision stage. Teaching materials that have been developed have seven units consisting of materials, examples, exercises, and evaluations. The results showed that the average of (I) the expert team trial was $90 \%$, (2) the practitioner trial was $9 \mathrm{I} \%$, and (3) the field test was $89 \%$, so the product was feasible to be implemented in the learning process. Therefore, learning to write poetry is recommended to use teaching materials to write poetry using modeling techniques that can make it easier for students to write poetry.

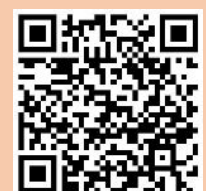

Copyright@2020, Marista Dwi Rahmayantis \& Nurlailiyah This is an open access article under the CC-BY-3.0 license

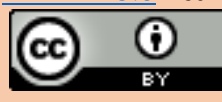

\begin{tabular}{ll}
\hline Keywords & Writing poetry, Developing teaching materials, Modeling techniques \\
\hline How to Cite & Rahmayantis, M. D., \& Nurlailiyah, N. (2020). Pengembangan materi bahan ajar menulis puisi dengan \\
& $\begin{array}{l}\text { menggunakan teknik pemodelan di SMPN I Tulungagung. KEMBARA: Jurnal Keilmuan Bahasa, Sastra, } \\
\text { dan Pengajarannya (e-Journal), 6(2), 243-254. doi: https://doi.org/I0.22219/kembara.v6i2.I4025 }\end{array}$ \\
\hline \hline
\end{tabular}

\section{PENDAHULUAN}

Kegiatan menulis sastra dilakukan melalui proses belajar yang berlangsung secara terus menerus. Kegiatan menulis juga dapat mendorong siswa untuk menuangkan ide, pendapat, perasaan dan pikiran yang berupa bahasa tulis. Oleh karena itu, kegiatan menulis dipandang sebagai sebuah kegiatan yang tidak hanya melibatkan fisik, tetapi juga pikiran dan perasaan. Kegiatan menulis sastra dilakukan melalui proses belajar yang berlangsung secara terus menerus. Kegiatan menulis juga dapat mendorong siswa untuk menuangkan ide, pendapat, perasaan dan pikiran yang berupa bahasa tulis. Oleh karena itu, kegiatan menulis dipandang sebagai sebuah kegiatan yang tidak hanya melibatkan fisik, tetapi juga pikiran dan 
perasaan. Wulandari, Fuady, \& Sumarwati (2012) menyatakan bahwa menulis adalah suatu keterampilan yang harus terus dilatih. Tingkat keseringan kita untuk menulis menuangkan ide gagasan sangat berpengaruh dengan perilaku kita dalam menulis. Semakin sering berlatih menulis, kesulitan dalam menulis akan terhindari. Hal ini sejalan dengan pernyataan Roekhan (I99I) bahwa menulis puisi merupakan salah satu bentuk menulis kreatif sastra. Menulis kreatif sastra adalah suatu proses penciptaan karya sastra.

Menulis puisi sebagai kegiatan menulis sastra merupakan salah satu kegiatan untuk menghasilkan sebuah tulisan. Pengembangan kreativitas dan berpikir ilmiah dapat dilakukan dengan menulis. Menuangkan ide dan gagasan ke dalam sebuah tulisan adalah cara terbaik untuk meningkatkan keterampilan menulis. Dalam menulis puisi melalui tahapan-tahapan tertentu. Proses melampaui tahapan dari memunculkan ide sampai menghasilkan tulisan berupa puisi disebut proses kreatif. Pratiwi, Maryaeni, \& Suwignyo (2016) menyatakan bahwa ada tiga unsur dalam proses kreatif, pertama, untuk memunculkan ide baru dan membangunnya dibutuhkan sebuah kreativitas, kedua, memanfaatkan bahasa, ketiga, aspek kebaruan dalam sastra, untuk menjadi inovasi baru dalam dunia sastra.

Fokus pengamatan saat siswa berlatih menulis puisi adalah proses kreatif saat menulis puisi dan eksplorasi pemikiran daya pikir, imajinasi siswa dalam mengkreasikan kemampuan menulis puisinya. Proses dalam menulis puisi biasa disebut proses kreatif, dan proses kreatif dari masing-masing penulis adalah berbeda. Proses kreatif tersebut akan berpengaruh dengan puisi yang dihasilkan oleh penulis Pratiwi, Maryaeni, \& Suwignyo (2016). Kegiatan menulis puisi dapat melatih kepekaan emosi dan daya imajinasi siswa melalui pengungkapan bahasa indah dan multimakna. Jabrohim \& Sayuti (200I) berpendapat bahwa menulis puisi adalah suatu kegiatan seorang intertekstual yakni kegiatan yang benarbenar cerdas, menguasai bahasa, luas wawasan dan peka terhadap perasaan. Sejalan dengan pendapat di atas, kegiatan menulis puisi dikembangkan dengan latihan mempertajam perasaan, penalaran, daya khayal dan kepekaan terhadap sesuatu.

Habibi, Chandra, \& Azima (2019) menyatakan bahwa pembelajaran sastra terdiri atas apresiasi sastra reseptif dan apresiasi sastra produktif. Apresiasi sastra reseptif menekankan pada proses penikmatan yang dapat dilakukan melalui kegiatan membaca, mendengarkan atau menonton pertunjukan drama dan pembacaan puisi. Apresiasi sastra ekspresif atau produktif dapat dilakukan dengan melatih siswa untuk menulis dan membaca puisi, menulis cerita atau sinopsis, dan bermain drama. Kegiatan pembelajaran menulis dibelajarkan di setiap jenjang pendidikan, salah satunya di tingkat Sekolah Menengah Pertama. Pembelajaran menulis puisi di SMP tersebut dengan memfokuskan kajiannya pada bait, rima, dan irama. Menulis puisi merupakan kegiatan yang berkelanjutan yang artinya penulis harus melalui tahapan demi tahapan agar mendapatkan hasil tulisan yang diinginkan. Tahapan penulisan tersebut adalah tahap awal atau tahap pra-menulis dimana dalam tahap ini penulis harus mencari inspirasi ide sebagai bahan menulis. Tahap selanjutnya adalah tahap menulis, dimana penulis mulai menuangkan ide dan gagasannya yang telah diimajinasikan ke dalam tulisan. Tahap akhir dari menulis ini adalah tahap pasca menulis, kegiatan pasca menulis adalah menyunting hasil tulisan.

Selaras dengan pendapat Kitao \& Kitao (2016) bahwa pembelajaran bahasa dan sastra memiliki lima komponen penting yaitu siswa, guru, materi, metode pembelajaran, dan evaluasi. Bahan ajar yang akan dikembangkan dalam penelitian ini mengadaptasi pembelajaran dengan strategi pemodelan, dan bahan ajar yang dikembangkan di dalamnya terdapat evaluasi di setiap unitnya. Menurut Rahmayantis (2016), pembelajaran tidak selalu berhasil dan menemukan hambatan, ketidak berhasilan dan hambatan tersebut salah satunya adalah tentang komunikasi antara siswa dan guru di kelas. Komunikasi tersebut berpengaruh ke dalam penyampaian dan penerimaan materi yang telah dipaparkan. Penting untuk memilih kemasan sintagmatik pembelajaran yang membangun munculnya kreativitas dan motivasi belajar siswa terhadap materi yang sedang dipelajari. Model pembelajaran yang merangsang munculnya sikap kreatif, motivasi, dan terjalinnya kerja sama sangat baik untuk dipilih guru untuk memfasilitasi pembelajaran (Purwati, 2019). Faktor motivasi belajar juga berpengaruh ke dalam proses belajar di dalam kelas. Jika motivasi belajar siswa rendah secara otomatis hasil yang di dapatkan juga rendah dan proses pembelajaran 
akan terkesan pasif dan monoton. Sebaliknya jika motivasi belajar siswa tinggi proses pembelajaran akan berjalan aktif dan seru. Menurut Wahyudi \& Doyin (2015) faktor yang memengaruhi motivasi belajar siswa rendah adalah minat belajar yang rendah dan penyajian pembelajaran yang masih berpusat kepada guru. Selain itu, pembelajaran yang searah membuat siswa kurang bisa mengeksplorasi atau melatih daya imajinasinya.

Kegiatan pembelajaran akan lebih optimal jika sumber bahan belajar yang digunakan oleh siswa dan strategi yang digunakan oleh guru dalam pembelajaran dapat menciptakan suasana belajar yang menyenangkan. Seperti halnya kegiatan pembelajaran, pengembangan bahan ajar juga membutuhkan sebuah strategi pembelajaran tertentu. Salah satu strategi pembelajaran yang dibutuhkan untuk mengatasi hambatan pembelajaran yang dialami siswa dan untuk mengembangkan bahan ajar menulis puisi adalah strategi pemodelan. Strategi pemodelan adalah salah satu komponen yang terdapat dalam pembelajaran kontekstual. Pembelajaran kontekstual merupakan pembelajaran dimana guru memberi contoh langsung fenomena yang ada di kehidupan sehari-hari yang dekat dengan kehidupan siswa. Pembelajaran konteksttual membuat replica dunia nyata ke dalam kelas. Menghubungkan fenomena dalam kehidupan sehari-hari dengan ilmu pengetahuan yang dimiliki (Nurhadi, 2004). Menurut Sanjaya (dalam Fitri, 2016), teknik pemodelan adalah teknik pembelajaran yang menampilkan alat peraga atau contoh ke depan siswa yang nantinya dapat menginspirasi siswa bahkan dapat ditiru oleh siswa. Teknik pemodelan sama halnya dengan mendemonstrasikan sesuatu kepada siswa. Selain itu, tujuan teknik pemodelan menurut Noviantari (2013) adalah mendorong terjadinya proses belajar pada diri sendiri. Dalam hal ini guru menyiapkan model atau contoh yang dapat ditiru oleh siswanya.

Strategi pemodelan adalah pembelajaran yang menampilkan contoh-contoh kepada siswa secara langsung seperti dalam kehidupan sehari-hari. Strategi pemodelan memiliki empat fase yaitu (I) fase perhatian; (2) fase rentensi; (3) fase reproduksi; dan (4) fase motivasi (Ngalimun, 2016). Siki, Sunoto, \& Roekhan (2017) menyatakan bahwa strategi pemodelan memiliki keunggulan dan kelemahan. Keunggulan teknik pembelajaran pemodelan ini adalah, dilihat dari segi siswa. Siswa dapat meniru dan mengeksplorasi sesuai dengan ide, gagasan, keinginannya yang disesuaikan dengan kehidupan sehari-hari. Ada keunggulan pasti ada kelemahan, kelemahan teknik pemodelan ini dilihat dari segi guru yang harus aktif menjadi model dan harus mencermati pembelajaran secara rinci dan fokus kepada kegiatan yang dilakukan oleh siswa hal ini akan menambah kerepotan bagi guru. Priansa (2017) menjelaskan bahwa kegiatan belajar mengajar dirancang dengan teknik pemodelan adalah kegiatan yang berfokus pada kegiatan edukatif siswa yang akan mengontruksi sendiri pemahamannya, setelah disajikan contoh-contoh oleh guru. Tugas guru menjadi fasilitator, sehingga guru tidak harus melakukan ceramah ataupun menyampaikan materi dari awal pertemuan sampai akhir pertemuan yang mengakibatkan kebosanan pada siswa. Siswa berusaha sendiri membangun pemahamannya dan aktif mengembangkan ide dan gagasan tersebut. Hal ini memerlukan sebuah bahan ajar dalam pembelajaran untuk membantu kelancaran pembelajaran.

Bahan ajar merupakan sajian materi, informasi, latihan, dan evaluasi yang disusun sesuai kriteria pengembangan bahan ajar dengan sistematis yang dapat mempermudah proses belajar siswa dan penyampaian materi dan informasi oleh guru (Pannen \& Purwanto, 200I). Guru akan memeroleh pedoman pembelajaran yang di dalamnya berisi sajian materi secara teoritis maupun praktis, latihanlatihan, dan evaluasi yang disesuaikan dengan kompetensi dasar yang akan dikembangkan. Saputro (2017) menyatakan bahwa buku ajar merupakan pedoman, petunjuk, materi, serta alat evaluasi yang mempunyai peranan penting bagi siswa untuk belajar dan mengembangkan ilmunya serta bagi guru untuk mengarahkan siswanya. Ulumuddin (2013) menyatakan bahwa bahan ajar adalah sebuah kumpulan materi yang diberikan guru kepada siswa secara langsung untuk membantu proses pembelajaran. Dengan bahan ajar siswa diharapkan mampu menguasai kompetensi dasar yang akan diajarkan. Bahan ajar hendaknya dipilih atau dikembangkan sesuai dengan kompetensi dasar yang akan diajarkan. Masalah-masalah yang timbul berkenaan dengan pemilihan bahan ajar menyangkut jenis, cakupan, urutan, perlakuan (treatment) terhadap materi pembelajaran dan sumber bahan ajar.

Marista Dwi Rahmayantis \& Nurlailiyah, Pengembangan materi bahan ajar menulis puisi dengan menggunakan teknik pemodelan di SMPN 1 Tulungagung 
Materi pembelajaran yang akan dikembangkan perlu ditentukan dengan tepat karena pengembangan materi pembelajaran memerlukan metode, media penyampai, dan cara menilai atau mengevaluasi. Pengembangan materi dari yang mudah ke materi yang lebih kompleks atau yang lebih rumit. Kedalaman materi disesuaikan dengan kebutuhan, sajian bahan ajar disajikan secara sistematis. Agar kegiatan dalam bahan ajar dapat diikuti siswa dengan baik selayaknya bahan ajar tersebut diberi treatment atau perlakuan yang tepat. Kristian, Suyono, \& Sunaryo (2016) menyatakan bahwa bahan ajar memiliki peranan yang penting dalam pembelajaran. Bahan adalah alat pembelajaran yang strategis bagi guru dan siswa, sehingga dapat dikatakan bahan ajar memiliki peran yang penting dalam pembelajaran. Untuk meningkatkan daya tarik dalam pembelajaran bahan ajar hendaknya disusun dan dilengkapi kegiatan yang inovatif dan dapat menumbuhkan minat belajar siswa. Tujuan penyusunan bahan ajar adalah mempersiapkan pembelajaran dengan bahan-bahan yang bersifat kebaruan dan tidak monoton dari tahun ke tahun sesuai perkembangan zaman. Bahan ajar ditampilkan dengan cara yang baru dengan menyisipkan teknik pembelajaran yang baru dan menarik.

Bahan ajar yang baik adalah bahan ajar yang memenuhi kriteria valid, bermanfaat, memotivasi dan dapat diimplementasikan dalam pembelajaran. Bahan ajar hendaknya memiliki urutan yang jelas, pembelajaran dimulai dari yang sederhana ke yang lebih rumit. Bahan ajar diawali dengan menjelaskan tujuan interaksional yang perlu dicapai setelah melakukan pembelajaran, bahan ajar juga harus mampu memotivasi siswa untuk lebih rajin belajar, dan menarik bagi siswa, bahkan bahan ajar harus mampu menyediakan bimbingan dan latihan pada siswa (Prastowo, 201I). Penentuan kriteria kelayakan komponen bahan ajar telah diuraikan oleh Muslich (2010) bahwa beberapa kriteria kelayakan isi bahan ajar yang harus dipenuhi, yakni (I) uraian materi yang akan dikembangkan disesuaikan dengan standar kompetensi (SK) dan kompetensi dasar (KD); (2) keakuratan materi; (3) materi pendukung pembelajaran. Dalam memilih, menentukan, dan mengembangkan suatu bahan ajar atau materi ajar harus memperhatikan kriteria atau karakteristik materi ajar. Dalam hal ini pendidik harus memperhatikan empat kriteria yang harus terpenuhi dalam materi ajar, yaitu (I) cakupan isi, (2) penyajian, (3) keterbacaan, dan (4) kegrafikan. Keempat kriteria tersebut harus terpenuhi agar materi yang dipilih atau dikembangkan dapat dikatakan baik atau layak digunakan sebagai sumber informasi dalam pembelajaran (Arsanti, 2018).

Penelitian tentang pembelajaran menulis puisi pernah dilakukan Purwati (2019); Pratiwi, Maryaeni, \& Suwignyo (2016); Rosita (2018); Ulumuddin (2013); Wahyudi \& Doyin, (2015); Wicaksono, Roekhan, \& Hasanah (2018) penelitian-penelitian tersebut memfokuskan proses pembelajaran dengan cara mengembangkan metode pembelajaran maupun mengembangkan bahan ajar untuk menulis puisi agar dapat meningkatkan pembelajaran menulis puisi. Sehubungan dengan kenyataan di lapangan selain hasil belajar menulis puisi kurang, bahan ajar sebagai sarana penampung materi, latihan, dan evaluasi belum digunakan. Oleh karena itu, dalam pembelajaran menulis puisi dibutuhkan sebuah bahan ajar yang dapat membantu siswa dan guru pada saat pembelajaran. Dalam pengembangan bahan ajar menulis puisi memerlukan sebuah teknik pembelajaran, agar pembelajaran tersebut dapat tersusun secara sistematis dan dapat meningkatkan daya tarik siswa dalam pembelajaran. Adapun teknik pembelajaran yang digunakan dalam pengembangan bahan ajar menulis puisi adalah teknik pemodelan. Teknik pemodelan yang bersumber dari pembelajaran kontekstual dianggap mampu membantu menciptakan suasana belajar yang lebih menarik. Dalam pembelajaran menggunakan teknik pemodelan siswa diajak untuk menyaksikan sebuah demonstrasi atau peragaan yang ada dalam kehidupan nyata sehari-hari.

Beberapa penelitian yang pernah membahas tentang teknik pemodelan ini adalah Fitri (2016); Noviantari (2013); Siki, Sunoto, \& Roekhan (2017) dalam penelitian tersebut menerapkan teknik pemodelan pada pembelajaran menulis surat, menyunting karangan, dan menulis cerpen. Berdasarkan penelitian yang telah ada pengembangan bahan ajar menulis puisi dengan teknik pemodelan belum pernah dilakukan. Berbeda dengan penelitian terdahulu yang pernah dilakukan, penelitian pengembangan ini difokuskan ke dalam materi dan sistematika bahan ajar menulis puisi dengan menggunakan metode pemodelan. Menulis puisi merupakan salah satu kompetensi dasar yang harus dikuasai di jenjang SMP 
kelas VII. Pada penelitian pengembangan ini, kompetensi menulis puisi baru difokuskan pada puisi remaja. Dalam puisi baru masih tetap mempertahankan penggunaan bait, irama, dan rima. Puisi baru yang memfokuskan pada contoh puisi remaja yang berisi pengalaman-pengalaman khas remaja seperti peristiwa di sekolah, persahabatan, dan lingkungan sosial.

Berdasarkan hasil observasi dan hasil wawancara guru pada tahap pra-pengembangan yang dilakukan pada subjek penelitian yaitu SMP kelas VII, diperoleh kenyataan bahwa pembelajaran menulis puisi menjadi pembelajaran yang kurang diminati oleh siswa. Hal tersebut dipicu oleh beberapa hal yaitu lingkungan belajar yang kurang memadai, rendahnya minat siswa untuk belajar menulis puisi, kesulitan siswa untuk memunculkan ide menulis puisi, bahan ajar yang kurang memadai dan lengkap untuk pembelajaran menulis puisi, serta strategi yang kurang tepat yang digunakan oleh guru. Dalam kegiatan pada saat analisis kebutuhan selain melakukan wawancara kepada guru dan siswa tentang pembelajaran menulis puisi, dilakukan pula pengamatan tentang pembelajaran menulis puisi yang dilakukan di dalam kelas. Pembelajaran menulis puisi ini dilakukan dengan metode konvensional. Metode ini diawali dengan ceramah, penjelasan materi belajar, penugasan, dan memanfaatkan lembar kerja siswa (LKS) yang telah dimiliki siswa dan guru. Pembelajaran belum memanfaatkan bahan ajar khusus menulis puisi maupun media pembelajaran untuk menulis puisi.

Melihat kenyataan dari kondisi yang terjadi di lapangan, sebagian dari siswa mengalami hambatan dalam pembelajaran menulis puisi, siswa kurang mampu ketika diminta untuk menulis puisi karena merasa kesulitan untuk menentukan ide, mencari diksi yang tepat, dan merangkai diksi menjadi puisi. Hal ini tampak dari nilai menulis puisi yang siswa yang mendapatkan nilai kurang dari kriteria ketuntasan minimal (KKM) dengan persentase 60\%. Kesulitan yang dialami siswa dalam pembelajaran menulis puisi merupakan hambatan bagi guru dalam melaksanakan pembelajaran menulis puisi yang menyenangkan. Salah satu tugas guru dalam kegiatan pembelajaran adalah memilih bahan atau sumber belajar dan menentukan strategi yang tepat. Menurut Irwanti (2017), proses pembelajaran tidak akan terlepas dengan adanya materi pembelajaran dan bahan ajar yang digunakan. Sebuah materi pembelajaran sangat berperan penting dalam kegiatan pembelajaran. Seorang guru harus menjelaskan materi tersebut secara tuntas.

Penelitian dan pengembangan ini dapat dilakukan karena dengan mengembangkan bahan ajar dapat membantu guru bahkan mempermudah guru dalam menyampaikan materi, latihan, dan evaluasi pembelajaran menulis puisi kepada siswa. Dengan adanya bahan ajar menulis puisi siswa juga bisa mandiri dalam pembelajaran tidak menggantungkan guru untuk menyampaikan materi. Teknik pemodelan yang erat kaitannya dengan kehidupan sehari-hari dapat mempermudah siswa untuk membantu membentuk ide dan gagasan dalam menulis puisi. Contoh dan demonstrasi yang menampilkan kegiatan yang dekat dengan kehidupan siswa dapat membantu menumbuhkan inspirasi dan ide untuk menulis puisi. Oleh karena itu, penelitian ini memfokuskan kajian terhadap pengembangan bahan ajar menulis puisi dengan menggunakan teknik pemodelan. Tujuan dari penelitian ini adalah untuk mengembangkan deskripsi isi, bahasa, dan sistematika sajian bahan ajar menulis puisi dengan strategi pemodelan untuk siswa SMP kelas VII SMPN I Tulungagung.

\section{METODE}

Dalam mengembangkan bahan ajar menulis puisi untuk siswa SMP digunakan model pengembangan model procedural atau bertahap yang mengadaptasi model desain pembelajaran Dick and Carey yang pertama kali dikembangkan oleh Walter Dick dan Lou Carey. Model Dick, Carey, \& Carey (2009) adalah salah satu dari model prosedural, yaitu model yang menyarankan agar penerapan prinsip desain pembelajaran disesuaikan dengan langkah-langkah yang sistematis dan harus ditempuh secara berurutan.

Model desain pengembangan Dick dan Carey dirumuskan dalam langkah-langkah pengembangan bahan ajar menulis puisi sebagai berikut: (I) identifikasi yang meliputi tujuan pembelajaran, (2) melakukan analisis kebutuhan dalam pembelajaran, (3) identifikasi perilaku dan karakteristik siswa, (4) perumusan tujuan capaian pembelajaran, (5) pengembangan tes, (6) pengembangan metode dan strategi 
pembelajaran, (7) pengembangan materi ajar (8) penilaian formatif (9) revisi pembelajaran, dan (I0) evaluasi akhir. Model desain Dick dan Carey digambarkan pada Gambar I.

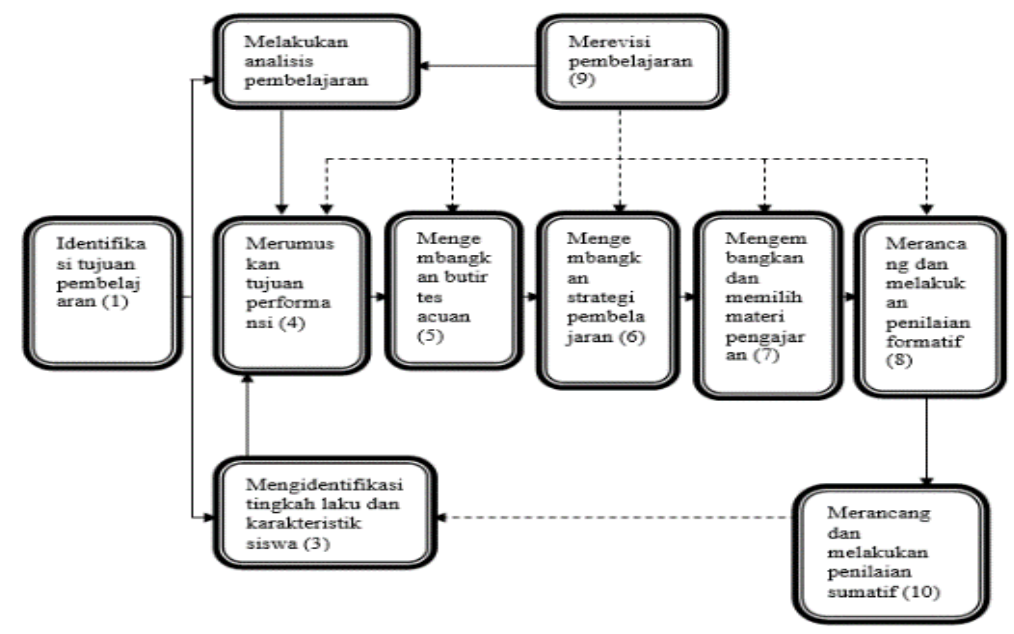

Gambar I. Model Desain Dick dan Carey

Lebih lanjut, Mbulu \& Suhartono (2004) menjelaskan mengenai desain pembelajaran model Dick dan Carey sebagai berikut.

(I) Identifikasi tujuan pembelajaran yaitu menentukan apa saja tujuan yang ingin dicapai dalam pembelajaran.

(2) Melakukan analisis pembelajaran yaitu menentukan kemampuan apa saja yang terlibat dalam pembelajaran dengan mengidentifikasi keterampilan yang ingin dicapai melalui penjabaran indikator.

(3) Mengidentifikasi tingkah laku dan karakteristik siswa yaitu identifikasi karakter khusus siswa yang memiliki keterampilan yang berhubungan dengan rancangan aktivitas pembelajaran yang akan dilakukan.

(4) Merumuskan tujuan performansi yaitu menguraikan tujuan secara lebih spesifik pada tiap tahapan pembelajaran.

(5) Mengembangkan butir tes acuan yaitu megembangkan butir tes untuk mengukur kemampuan dan ketercapaian kompetensi dasar pada siswa.

(6) Mengembangkan strategi pembelajaran yaitu menentukan aktivitas instruksional yang membantu dalam pencapaian tujuan meliputi aktivitas preinstruksional, penyampaian informasi, praktik, balikan, dan tes.

(7) Mengembangkan dan memilih materi pengajaran yaitu berkaitan dengan strategi yang digunakan untuk menghasilkan pengajaran yang meliputi petunjuk untuk siswa, bahan pelajaran, tes, dan panduan guru.

(8) Merancang dan melakukan penilaian formatif dilakukan untuk mengumpulkan data yang digunakan untuk mengindentifikasi peningkatan pengajaran.

(9) Merevisi pembelajaran yaitu data dari evaluasi sumatif yang telah dilakukan pada tahap sebelumnya diringkas dan dianalisis serta diinterpretasikan untuk diidentifikasi kesulitan yang dialami oleh siswa dalam mencapai tujuan pembelajaran dan juga masukan dari hasil implementasi dari pakar/validator.

(I0) Merancang dan melakukan penilaian sumatif yaitu mempelajari efekivitas keseluruhan kegiatan yang dilakukakansetelah tahap evaluasi formatif.

Selanjutnya model Dick dan Carey diadaptasikan untuk merumuskan model pengembangan RPP dan pengembangan bahan ajar menulis puisi yang meliputi empat tahapan yaitu (I) tahap 
prapengembangan/persiapan, (2) tahap pengembangan, (3) tahap uji coba dan (4) tahap revisi. Tahapantahapan dalam mengembangkan bahan ajar digambarkan Gambar 2.

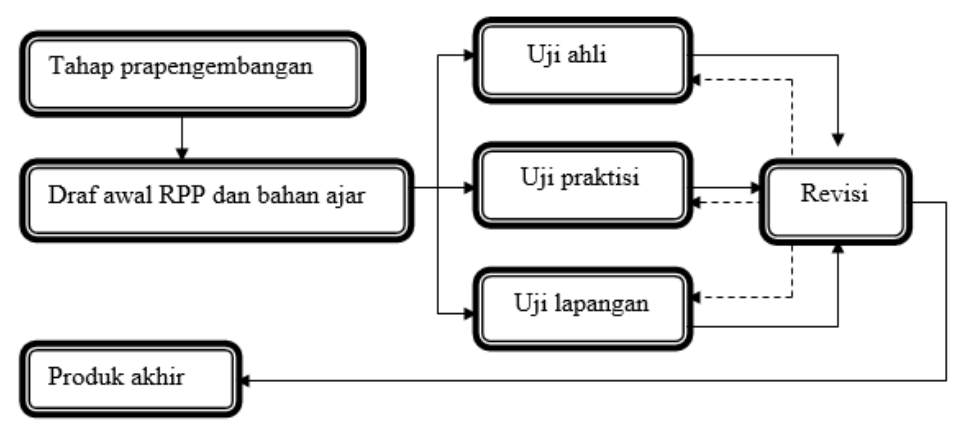

Gambar 2. Tahapan Pengembangan Bahan Ajar

Prosedur pengembangan yang digunakan dalam penelitian ini meliputi langkah-langkah prosedural untuk mengembangkan produk yang berupa Rencana Pelaksanaan Pembelajaran (RPP) dan bahan ajar yang termuat dalam tahapan-tahapan sebagai berikut: (I) tahap pra-pengembangan; (2) tahap pengembangan meliputi uji coba produk; (3) tahap uji coba; dan (4) tahap revisi.

\section{HASIL DAN PEMBAHASAN}

Buku cetak yang ber ISBN merupakan produk yang dihasilkan dalam penelitian ini. Bahan ajar ini terdiri dari beberapa unit (mozaik) materi beserta evaluasi. Pengembangan materi pada bahan ajar ini dimulai dari yang sederhana menuju materi yang kompleks. Produk yang dikembangkan adalah bahan ajar untuk keterampilan menulis puisi siswa kelas VII SMP.

Bahan ajar ini dikembangkan dari segi isi, penyajian, dan kelayakan bahasa. Dari segi isi, materi yang digunakan dalam mengembangkan bahan ajar ini diperoleh dari berbagai sumber yang telah disesuaikan dengan standar kompetensi, kompetensi dasar, kebutuhan siswa, tingkat perkembangan intelektual. Materi tersebut memberikan kesempatan kepada siswa untuk melakukan eksplorasi pengetahuan, keterampilan, dan sikap melalui berbagai kegiatan belajar agar memudahkan siswa belajar mandiri dan berkelompok dalam mencapai kompetensi dasar yang diinginkan. Bahan ajar ini juga memuat pesan-pesan penting yang secara tidak langsung tersampaikan kepada siswa. Pesan-pesan penting tersebut termuat dalam tahapan-tahapan kegiatan belajar yang dilakukan oleh siswa melalui bahan ajar ini.

Pengembangan bahan ajar dari segi penyajian memiliki beberapa indikator. Indikator tersebut meliputi kevariasian materi, ketersediaan pembangkit motivasi yang dibagi lagi ke dalam dua kriteria. Indikator berikutnya adalah keruntutan dan konsistensi konsep, keotentikan materi, keaktualan contohcontoh dalam media, kesesuaian sajian bahan ajar dengan alur berpikir induktif, dan ketersediaan bahan pendukung. Dari segi penyajian, bahan ajar ini dirancang menarik dengan pewarnaan yang disesuaikan dengan tingkat berpikir siswa. Penyajian kegiatan dalam media ini juga disusun sesuai dengan pola berpikir siswa, dari materi yang sederhana ke materi yang lebih kompleks, dari yang konkret ke yang abstrak. Sesuai dengan hal tersebut, maka pola berpikir induktif digunakan dalam penyusunan penyajian bahan ajar ini.

Dari segi kelayakan bahasa dalam bahan ajar, indikator yang diberikan adalah kesesuaian penggunaan bahasa yang terbagi ke dalam dua kriteria, yaitu kesesuaian penggunaan bahasa dengan tingkat perkembangan intelektual siswa dan kesesuaian penggunaan bahasa dengan tingkat emosional siswa. Indikator berikutnya adalah bentuk bahasa yang terdiri atas dua kriteria, yaitu, ketepatan penggunaan ejaan dan tanda baca dan kesesuaian pilihan kata dengan kaidah bahasa Indonesia yang benar. Indikator selanjutnya adalah kekomunikatifan bahasa yang terdiri atas kriteria mengenai penyajian bahasa yang komunikatif dan grafika yang ditampilkan dalam bahan ajar. Indikator terakhir adalah kemudahan penyampaian pesan kepada siswa. 
Bahasa yang digunakan dalam bahan ajar ini layak diimplementasikan karena memiliki susunan kata, bentukan kata, dan kalimat yang sesuai dengan perkembangan berpikir siswa. Selain itu, ejaan, tanda baca, dan aspek-aspek mekanik lainnya digunakan secara tepat. Bahasa yang digunakan dalam setiap tahapan kegiatan dalam bahan ajar ini sangat komunikatif, sehingga pengguna produk dapat segera memahami maksud perintah-perintah yang terdapat dalam bahan ajar.

Bahan ajar yang dikembangkan telah divalidasi dengan materi yang mengacu pada standar kompetensi yang sesuai dengan KI3 dan disajikan secara bertahap untuk memudahkan siswa. Pengembangan materi yang terdapat dalam bahan ajar ini adalah sebagai berikut.

Materi yang disajikan dibagi menjadi 7 unit (mozaik) adalah sebagai berikut:

a) Hakikat puisi,

b) Menjaring ide untuk menulis puisi,

c) Menentukan tema puisi

d) Menentukan diksi (kata-kata puitis)

e) Berlatih menulis puisi,

f) Cara membuat kata-kata puisi lebih manis

g) Menentukan judul yang menarik

h) Merefleksikan puisi yang telah ditulis

Bahan ajar ini dikembangkan bertumpu pada standar kompetensi menulis puisi. Pada bagian ini terdapat empat poin penting, yaitu (I) materi tentang menulis puisi, (2) latihan menulis puisi, (3) refleksi. Bahan ajar menulis puisi ini menyajikan materi yang dilengkapi dengan contoh ilustrasi yang dekat dengan kehidupan siswa, agar siswa dengan mudah memahami materi tersebut. Materi disajikan bervariasi (tidak monoton) supaya minat belajar siswa lebih meningkat lagi karena menemukan hal yang baru dan menyenangkan. Sajian bahan ajar ditampilkan secara sistematis, dengan mengedepankan permainan warna dan gambar yang menarik bertujuan untuk memberi semangat kepada siswa dan memotivasi siswa dalam belajar. Bahasa yang digunakan pun bahasa yang komunikatif agar siswa bisa berinteraksi secara santai dengan bahan ajar. Agar minat siswa untuk mempelajari bahan ajar meningkat disajikan pula pembangkit motivasi siswa berupa ilustrasi, gambar, animasi, dan sajian warna-warna yang disesuaikan dengan tingkat kemenarikan siswa kelas VII SMP. Evaluasi disesuaikan dengan tingkat kerumitan di setiap kegiatan. Hal ini sejalan dengan pendapat Kristian, Suyono, \& Sunaryo (2016) bahwa sistematika dan sajian bahan ajar hendaknya ditampilkan dengan menarik agar siswa menyukai tampilan bahan ajar tersebut, sehingga dapat memotivasi belajar siswa.

Bahan ajar ini juga disusun dengan konsep yang runtut dan konsisten. Sistematika penyajian dalam bagian pendahulu memuat materi prasyarat untuk memahami bahan ajar utama yang disajikan, yaitu praktik menulis puisi. Pola pengembangan materi pada bahan ajar menulis puisi ini menggunakan pola pengembangan induktif. Alur berpikirnya dari hal sederhana ke hal yang rumit, dari mudah ke yang sulit, dan pola urutan penyajiannya disusun secara sistematis dan konsisten di setiap kegiatan.

\section{PEMBAHASAN}

Masalah yang sering dihadapi guru berkenaan dengan bahan ajar adalah guru memberikan bahan ajar atau materi pembelajaran terlalu luas atau terlalu sedikit, terlalu mendalam atau terlalu dangkal, urutan penyajian yang tidak tepat, dan jenis materi bahan ajar yang tidak sesuai dengan kompetensi yang ingin dicapai oleh peserta didik. Untuk itu, perlu dikembangkan bahan ajar pada aspek bersastra khususnya kemampuan menulis puisi (Ulumuddin, 2013). Pengembangan sebuah bahan ajar untuk mendapatkan bahan ajar yang baik hendaknya melalui tahap pra-pengembangan, pengembangan, dan penyebarluasan. Pada proses pra-pengembangan dilakukan analisis kebutuhan yaitu pengumpulan data terkait proses pembelajaran menulis puisi. Kegiatan dalam analisis kebutuhan ini adalah wawancara dengan guru beserta siswa terkait pembelajaran menulis puisi.

Bertolak dari penelitian sebelumnya inspirasi untuk melakukan penelitian pengembangan ini adalah penelitian dan pengembangan yang dilakukan oleh Wicaksono, Roekhan, \& Hasanah (2018) yang 
berjudul Pengembangan Media Permainan Imajinasi dalam Pembelajaran Menulis Puisi bagi Siswa Kelas $X$. Perbedaan yang mendasar dari penelitian ini dengan penelitian yang dilakukan oleh Wicaksono, Roekhan, \& Hasanah (2018) adalah hasil produk yang dikembangkan. Produk yang dikembangkan di penelitian ini adalah bahan ajar dan media pembelajaran. Fokus kajian pembelajaran adalah sama-sama pada pembelajaran menulis puisi. Penelitian Wicaksono, Roekhan, \& Hasanah (2018) menggunakan subjek penelitian siswa SMA kelas X dan penelitian ini menggunakan subjek siswa SMP kelas VII.

Penelitian dan pengembangan serupa juga dilakukan oleh Rosita (2018) tentang Pengembangan Model Pembelajaran TIMNAS untuk Menulis Puisi Siswa SMP Kelas VIII penelitian yang dilakukan Rosita menggunakan model pembelajaran TIMNAS (think, imajine, and Share on Group) dan dikembangkan untuk siswa Kelas VIII. Fokus pengembangan model yang disusun oleh Rosita mengacu pada kurikulum tingkat satuan pendidikan. Hasil pengembangan yang utama adalah model pembelajaran. Hal ini berbeda dengan penelitian dan pengembangan yang disusun merupakan fokus kajian pengembangan dan menghasilkan produk bahan ajar dan menggunakan kurikulum 2013.

Jika hasil penelitian dan pengembangan ini merupakan bahan ajar menulis puisi dengan melihat aspek isi (materi), bahasa, dan sajian berbeda dengan hasil penelitian dan pengembangan yang dilakukan Irwanti. Penelitian dan pengembangan terdahulu lainnya yang dilakukan oleh Irwanti pada tahun 2017 dengan judul Pengembangan Bahan Ajar Menulis Puisi Bebas Kelas VIII SMP XA Verius Tugumulyo. Hasil penelitian dan pengembangan yang dilakukan Irwanti adalah bahan ajar menulis puisi bebas berdasarkan dari tampilan dan kebahasaan.

Penelitian pengembangan bahan ajar menulis puisi ini fokus ke dalam isi (materi), bahasa, dan sajian bahan ajar. Agar dapat melihat tingkat kelayakan bahan ajar untuk dapat diimplementasikan ke dalam pembelajaran perlu melalui proses uji ahli pada tahap pengembangan. Dimana dalam proses ini digunakan sebagai dasar untuk menentukan layak dan tidaknya bahan ajar menulis puisi digunakan di sekolah. Uji ahli dilakukan untuk memvalidasi bahan ajar yang telah disusun. Uji ahli dilakukan kepada ahli pembelajaran dan ahli sajian bahan ajar. Uji praktisi dilakukan kepada guru, dan uji lapangan dilakukan kepada siswa kelas VII. Hasil uji ahli, praktisi, dan lapangan yang telah dilakukan berdasarkan aspek isi (materi), bahasa, dan sajian sebagaimana Gambar 3.

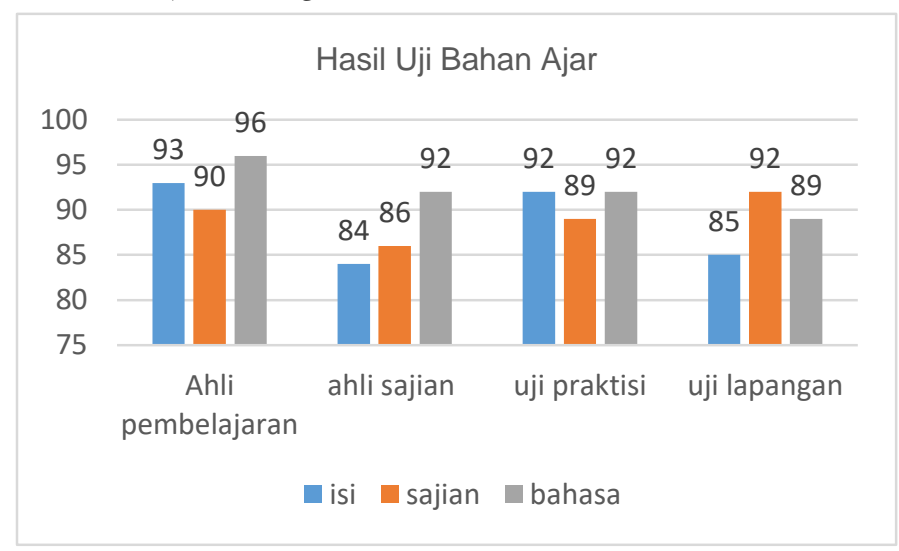

Gambar 3. Rerata Hasil Uji Ahli dan Uji Lapangan

Berdasarkan uji ahli yang dilakukan pada ahli pembelajaran rerata yang diperoleh adalah mendapatkan hasil 93\% pada aspek isi, 90\% pada aspek sajian, dan 96\% aspek bahasa. Dapat disimpulkan dari uji ahli pembelajaran yang dilakukan bahan ajar menulis puisi ini layak untuk diimplementasikan kepada pengguna.

Uji ahli kedua dilakukan kepada ahli di bidang sajian bahan ajar. Rerata yang diperoleh dari uji ahli tersebut adalah $84 \%$ dari segi isi, $86 \%$ dari segi sajian, dan $92 \%$ dari segi bahasa. Dari hasil rerata yang diperoleh pada validasi ahli sajian, bahan ajar dapat digunakan kepada pengguna yaitu guru dan siswa di sekolah. Validasi atau uji bahan ajar selanjutnya adalah kepada pengguna. Pengguna pertama adalah 
praktisi di sekolah yaitu guru. Tahap ini dilaksanakan, jika tahap validasi oleh uji ahli telah mendapatkan hasil tanpa merevisi produk. Pada tahap ini diperoleh hasil rerata $92 \%$ pada aspek isi, $89 \%$ pada aspek sajian bahan ajar, dan $92 \%$ pada aspek bahasa yang digunakan dalam bahan ajar. Tahap terakhir uji bahan ajar adalah uji bahan ajar yang dilakukan kepada pengguna di lapangan yaitu siswa. Uji lapangan kepada siswa dapat dilakukan jika tahap validasi kepada ahli dan praktisi telah dilalui dan mendapatkan hasil tanpa revisi. Dari uji lapangan kepada siswa yang dilakukan mendapatkan rerata hasil $85 \%$ pada aspek kedalaman isi, mendapatkan hasil $92 \%$ pada aspek sajian bahan ajar, dan mendapatkan rerata $89 \%$ pada aspek penggunaan bahasa.

Selaras dengan pernyataan (Pannen \& Purwanto, 200I) bahwa bahan ajar adalah bahan-bahan yang menyajikan informasi, pengalaman dan latihan yang disusun secara sistematis, sehingga memudahkan guru dan siswa dalam proses pembelajaran. Hal ini dapat dilihat dari hasil uji ahli dan lapangan yang didapatkan, bahwa bahan ajar menulis puisi yang disusun telah dapat diaplikasikan ke dalam pembelajaran agar dapat berjalan lebih efektif. Bahan ajar menulis puisi ini dapat digunakan oleh guru dan siswa untuk menunjang pembelajaran dan membantu siswa belajar menulis puisi dengan mandiri.

Pratama, Pratiwi \& Andajani (2016) menyatakan bahwa teks dalam bahan ajar secara umum disajikan dengan pola pengembangan sebab akibat dan perbandingan, agar siswa mampu mengimplikasikan ke dalam kehidupan nyata, dan teks dalam bahan ajar hendaknya memiliki tingkat keterbacaan tinggi. Materi, bahasa, dan sajian bahan ajar memiliki peran yang utuh pada saat pengembangan bahan ajar, karena fokus utama pengembangan bahan ajar adalah ketiga komponen tersebut.

Bahan ajar menulis puisi ini memiliki keunggulan dan kelemahan. Salah satu keunggulannya adalah bahan ajar ini mampu membantu guru dalam membelajarkan menulis puisi kepada siswa dengan lebih efektif. Kelemahan bahan ajar masih berupa cetak belum ada versi daringnya. Rencana ke depannya bahan ajar ini akan dibuat versi daring.

\section{SIMPULAN}

Pengembangan bahan ajar menulis puisi dengan strategi pemodelan ini difokuskan ke dalam tiga aspek, yaitu aspek, isi (materi), bahasa dan sistematika sajian. Dalam proses pengembangannya terdapat tiga tahap yaitu pra-pengembangan, pengembangan, dan penyebarluasan bahan ajar. Bahan ajar menulis puisi untuk kelas VII ini melalui proses uji ahli, uji praktisi, sebelum bahan ajar ini digunakan oleh pengguna yaitu siswa. Hasil uji ahli pembelajaran dan sajian dapat disimpulkan bahwa bahan ajar ini dapat diaplikasikan kepada pengguna. Hasil uji ahli mendapatkan rerata $90 \%$, hal ini telah melampaui batas minimal keefektifan implementasi bahan ajar.

Uji praktisi yang dilakukan kepada guru Bahasa Indonesia SMP mendapatkan rerata 90\% pada semua aspek, baik aspek isi, sajian maupun bahasa. Hal ini menandakan bahan ajar menulis puisi yang telah melalui dua tahap uji yaitu uji ahli dan uji praktisi telah layak untuk diaplikasikan kepada pengguna. Uji lapangan kepada siswa adalah tahapan terakhir dalam uji coba bahan ajar menulis puisi. Hasil dari uji coba menentukan keefektifan dari bahan ajar mampu untuk diimplementasikan ke dalam pembelajaran atau tidak. Rerata yang didapatkan dari uji lapangan tersebut adalah $89 \%$ hal ini menunjukkan bahwa bahan ajar telah siap untuk digunakan.

Bahan ajar yang telah dikembangkan dengan materi menulis puisi untuk siswa kelas VII dapat dikembangkan lebih lanjut untuk memaksimalkan manfaat yang diperoleh. Sebagai saran pemanfaatan dan diseminasi produk lebih lanjut adalah bahan ajar ini sebagai alternatif yang dapat dimanfaatkan siswa dan guru untuk pembelajaran menulis puisi. Bahan ajar ini dikemas dalam bentuk cetak, dan disarankan kepada pengguna untuk menggunakan bahan ajar ini urut dari depan karena bahan ajar ini disusun pertahap. Dengan demikian pengguna dapat memanfaatkan bahan ajar ini secara mandiri tanpa menggantungkan kepada guru, karena bahan ajar ini disusun secara bertahap dari materi yang sederhana ke yang lebih rumit. 
Bahan ajar ini disusun agar pengguna mampu memanfaatkannya secara mandiri, tetapi peran guru tidak boleh diindahkan. Guru tetap berperan dalam mendampingi siswa dalam pembelajaran dan penggunaan bahan ajar. Penyebarluasan atau diseminasi dari bahan ajar menulis puisi ini dapat dilakukan dengan bekerja sama forum MGMP Bahasa Indonesia SMP.

\section{UCAPAN TERIMA KASIH}

Penulis mengucapkan terima kasih kepada Lembaga Penelitian dan Pengabdian Kepada Masyarakat (LPPM) Universitas Nusantara PGRI Kediri yang telah memberikan dukungan dalam penelitian ini. Penulis juga mengucapkan terima kasih kepada semua pihak yang telah berkontribusi dalam penelitian ini, sehingga penelitian ini dapat terlaksana dan diselesaikan dengan baik.

\section{DAFTAR PUSTAKA}

Arsanti, M. (2018). Pengembangan bahan ajar mata kuliah penulisan kreatif bermuatan nilai-nilai pendidikan karakter religius bagi mahasiswa prodi PBSI, FKIP, UNISSULA. KREDO: Jurnal Ilmiah Bahasa dan Sastra, I(2), 69-88. doi: https:/ / doi.org/I0.24I76/kredo.vIi2.2I07

Dick, W., Carey, L., \& Carey, J.O. (2009). The systematic design of instruction 7th Ed. United State of America: Pearson Education.

Fitri, R. (2016). Penerapan teknik pemodelan untuk meningkatkan kemampuan menulis surat resmi siswa kelas VIII SMP. Jurnal Gramatika, 2(2), II8-I32. doi: I0.22202/jg.20I6.v2i2.1200

Habibi, M., Chandra, C., \& Azima, N. F. (2019). Pengembangan bahan ajar menulis puisi sebagai upaya mewujudkan literasi sastra di sekolah dasar. Elementary School Journal PGSD FIP UNIMED, Y(I), 8-I6. doi: https://doi.org/I0.24I I4/ esjpgsd.v9iI.I4297

Irwanti, E. (2017). Pengembangan bahan ajar menulis puisi bebas kelas 8 SMP Xaverius Tugumulyo. Jurnal KIBASP (Kajian Bahasa, Sastra dan Pengajaran), I(I), 32-49. doi: https://doi.org/I0.3I539/kibasp.vIiI.I05

Jabrohim, A \& Sayuti, S.A. (200I). Cara menulis kreatif. Yogyakarta: Pustaka Pelajar.

Kitao, K \& Kitao S.K. (2016). Selecting and developing teaching/learning material. The Internet TESL Journal. Diterima melalui http/:iteslj.org/Articles/Kitao-material.html, diakses pada tanggal: 27 September 2020

Kristian, N., Suyono, S., \& Sunaryo, S. (2016). Pengembangan bahan ajar menulis laporan penelitian berbasis pengayaan skemata bacaan. Jurnal Pendidikan: Teori, Penelitian, dan Pengembangan, I(2), 203-213. doi: http://dx.doi.org/I0.I7977/jp.vIi2.6I23

Mbulu, J., \& Suhartono. (2004). Pengembangan bahan ajar: Konsep-konsep dasar pengembangan bahan ajar. Malang: Universitas Negeri Malang.

Muslich, Masnur. (2010). Text book writing: Dasar-dasar pemahaman, penulisan, dan pemakaian buku teks. Yogyakarta: Ar-Ruzz Media.

Ngalimun. (2016). Strategi dan model pembelajaran. Yogyakarta: Aswaja Pressindo.

Noviantari, W. (20I3). Penerapan teknik pemodelan untuk meningkatkan kemampuan menyunting karangan argumentasi siswa kelas Xd SMA Negeri I Selemadeg. Jurnal Pendidikan Bahasa dan Sastra Indonesia Undiksha, I(5), I-I5. doi: http://dx.doi.org/I0.23887/jjpbs.vIi5.58 I

Nurhadi. (2004). Pembelajaran kontekstual dan penerapannya dalam KBK. Malang: UM Press.

Pannen, P., \& Purwanto. (200I). Penulisan bahan ajar. Jakarta: PAU-PPAI, Universitas Terbuka.

Purwati, P. D. (2019). Pengembangan model eklektik berbasis nilai luhur pancasila dalam pembelajaran menulis puisi rakyat kelas VII SMP. Jurnal Pendidikan Bahasa dan Sastra Indonesia, 8(I), I828. doi: https://doi.org/I0.I5294/jpbsi.v8iI.2I537

Prastowo, A. (20II). Pengembangan bahan ajar inovatif. Jakarta: Diva Press.

Pratama, F. Y., Pratiwi, Y., \& Andajani, K. (2016). Pengembangan bahan ajar menulis teks eksposisi bermuatan cinta lingkungan dengan strategi pemodelan untuk siswa kelas VII SMP. Jurnal 
Pendidikan: Teori, Penelitian, dan Pengembangan, I(3), 448-462. doi: http://dx.doi.org/I0.17977/jp.vIi3.617I

Pratiwi, Y. D., Maryaeni, M., \& Suwignyo, H. (2016). Kreativitas siswa dalam menulis puisi. Jurnal Pendidikan: Teori, penelitian, dan pengembangan, $I(5), \quad 835-843$. doi: http://dx.doi.org/I0.17977/jp.vIi5.6265

Priansa, D. J. (2017). Pengembangan strategi dan model pembelajaran. Bandung: Pustaka Setia.

Rahmayantis, M. D. (2017). Pengembangan bahan ajar membaca indah puisi untuk siswa SMP Kelas VII. KEMBARA: Jurnal Keilmuan Bahasa, Sastra, dan Pengajarannya (e-journal), 2(I), 47-56. doi: https://doi.org/I0.22219/kembara.v2iI.4043

Roekhan. (199I). Menulis kreatif: Dasar-dasar dan petunjuk penerapannya. Malang: YA3.

Roekhan. (I99I). Penulisan kreatif sastra: Buku penunjang perkuliahan. IKIP Malang: Depdikbud.

Rosita, F. Y. (2018). Pengembangan model pembelajaran timnas untuk menulis puisi siswa SMP Kelas VIII. KEMBARA: Jurnal Keilmuan Bahasa, Sastra, dan Pengajarannya (e-journal), 4(I), 35-47. doi: https://doi.org/I0.22219/kembara.v4iI.548I

Saputro, A. N. (2017). Pengembangan buku ajar menulis sastra yang berorientasi pada pembentukan karakter siswa. Jurnal Gramatika. Jurnal Penelitian Pendidikan Bahasa dan Sastra Indonesia, 3(2), I83-I93. doi: https:/ / doi.org/I0.22202/ig.2017.v3i2.2024

Siki, F., Sunoto, S., \& Roekhan, R. (2017). Upaya meningkatkan kemampuan menulis cerpen berdasarkan pengalaman pribadi dengan strategi pemodelan. Jurnal Pendidikan: Teori, Penelitian, dan Pengembangan, 2(I2), I679-I682. doi: http://dx.doi.org/I0.17977/jptpp.v2iI2.I0328

Ulumuddin, A. (20I3). Pengembangan bahan ajar menulis puisi berkonteks lingkungan peserta didik bermuatan nilai-nilai religius untuk madrasah aliyah. Sasindo, I(I), I-I3. doi: https://doi.org/I0.26877/sasindo.vIiI\%20Januari.423

Wahyudi, F. A., \& Doyin, M. (2015). Pengembangan buku pop up tiga dimensi sebagai media pembelajaran menulis puisi. Lingua, II(2), I-II. Retrieved from: https://journal.unnes.ac.id/nju/index.php/lingua/article/view/8764/5745

Wicaksono, H., Roekhan, R., \& Hasanah, M. (2018). Pengembangan media permainan imajinasi dalam pembelajaran menulis puisi bagi siswa kelas X. Jurnal Pendidikan: Teori, Penelitian, dan Pengembangan, 3(2), 223-228. doi: http://dx.doi.org/I0.17977/jptpp.v3i2.10526

Wulandari, T., Fuady, A., \& Sumarwati, S. (20I2). Peningkatan motivasi dan kemampuan menulis puisi melalui penerapan metode menulis berantai pada siswa sekolah menengah atas. BASASTRA, $I(\mathrm{I}), \quad$ 77-92. Retrieved https:// core.ac.uk/download/pdf/289787236.pdf 